\title{
PROTOTYPE APLIKASI PEMESANAN DAN PENGIRIMAN SERBUK KAYU OLEH CV.USAHA BERSAMA SEBAGAI SUPLIER PT.FUMAKILLA
}

\author{
Muhammad Rusdi ${ }^{1),}$ Haji Sirajudin ${ }^{2)}$, Muhammad Amin ${ }^{3)}$ \\ ${ }^{1}$ Fakultas Teknologi Informasi, Universitas Islam Kalimantan MAB Banjarmasin \\ Email : rusdimuhammad001@gmail.com \\ ${ }^{2)}$ Fakultas Teknologi Informasi, Universitas Islam Kalimantan MAB Banjarmasin \\ Email : uniska.siraj@gmail.com \\ ${ }^{3)}$ Fakultas Teknologi Informasi, Universitas Islam Kalimantan MAB Banjarmasin \\ Email : maminbjm58@gmail.com
}

\begin{abstract}
Abstrak
CV.Usaha Bersama Sebagai Salah satu Suplier perusahan obat nyamuk PT.Fumakilla cabang Banjarbaru selama ini menerima pesanan yang lumayan banyak dari PT.Fumakilla yaitu sekitar 14 ton dalam seminggu. Dalam seminggu mengalami minimal $2 x$ pemesanan dan pengiriman bahan serbuk ulin sebagai bahan dasar untuk campuran obat nyamuk fumakilla dan kayu bakar ulin sebagai bahan bakar pada oven pembuatan obat nyamuk tersebut. Selama ini pemesanan dilakukan secara manual yaitu melalui pencatatan di manual book saja. Maka kami membuatkan Prototype Aplikasi Pemesanan Dan Pengiriman Serbuk Kayu Oleh CV.Usaha Bersama Sebagai Suplier PT.Fumakilla berbasis web dengan menggunakan PHP dan Mysql
\end{abstract}

Kata Kunci : Fumakilla, MySQL,Prototype,PHP, Suplier

\section{PENDAHULUAN}

CV.Usaha Bersama adalah bentuk usaha dagang yang bergerak di bidang Suplier Serbuk kayu dan Kayu Bakar Ulin , didirikan oleh bpk.Mahlan pada tanggal 8 desember 2010 DI Kabupaten Tanah Bumbu. CV.Usaha Bersama adalah penyalur utama atau suplier Serbuk kayu dan kayu bakar pada PT.Fumakilla Cabang Banjarbaru . CV.Usaha Bersama Memiliki kurang lebih 10 karyawan. Saat ini untuk Pemesanan dan pengiriman bahan tersebut masih manual yaitu hnya menggunakan manual book saja. Padahal untuk kemudahan dan kecepatan pengiriman mereka menggunakan komputerisasi agar data - data bisa lebih cepat dan data pemesanan serta pengiriman sebelumnya masih bisa dilacak dengan mudah. CV.Karya Bersama Sebagai Salah satu Suplier perusahan obat nyamuk PT.Fumakilla cabang Banjarbaru selama ini menerima pesanan yang lumayan banyak dari PT.Fumakilla yaitu sekitar 14 ton dalam seminggu. Dalam seminggu mengalami minimal $2 x$ pemesanan dan pengiriman bahan serbuk ulin sebagai bahan dasar untuk campuran obat nyamuk fumakilla dan kayu bakar ulin sebagai bahan bakar pada oven pembuatan obat nyamuk tersebut.

Pemesanan dan Penjualan merupakan kegiatan yang mempengaruhi jumlah persediaan barang. Informasi yang dihasilkan akan membantu pemilik dalam memutuskan jumlah persediaan yang akan dibeli, maupun jumlah yang tersedia untuk dijual, serta mengontrol dan mengawasi jumlah aset persediaan. Dalam merancang dan membangun aplikasi ini nantinya mengacu pada penelitian orang lain tetapi tidak sama tempat judul penelitiannya seperti "Perancangan Sistem Informasi Penjualan dan Stok Barang di Toko Bazar Komputer", (Subekti, 2018) menggunakan Java dengan Database MySQL tetapi masih menggunakan pembukuan manual. Prnrlitian "Perancangan Database Sistem Penjualan menggunakan Delphi dan Miscrosoft SQL Server", (Ayuastrid, 2015) dengan Borland Delphi 7 hanya terbatas pada informasi penjualan secara umum. dan "Program Aplikasi Persediaan Barang pada PT. Panji Surya Abadi”, (Merianadesiyani, 2015) menggunakan Visual Basic, terjadi masukan dan keluarannya barang tidak terkontrol.

Dalam pengelolaan data pemesanan dan pengiriman CV.Usaha Bersama masih 
dilakukan secara manual. Maka diperlukan suatu sistem otomatis yang dapat membantu mereka dalam membuat pemesanan lebih mudah dan terdata serta langsung bisa memotong stok pada sistem dan data di CV.Usaha Bersama bisa lebih mudah dicari dan tersimpan dengan baik. Rumusan

Masalah yaitu Bagaimana Aplikasi Pemesanan dan pengiriman serbuk kayu Oleh CV Usaha Bersama sebagai suplier PT.Fumakilla dapat Mempermudah pemesanan dan pengiriman Barang serta dapat Memberikan Informasi data stok serta laporan penjualam pada CV. Usaha Bersama. Tujuan dari dibuatnya Penelitian Ini yaitu Membuat Prototype Aplikasi Pemesanan Dan Pengiriman Serbuk Kayu Oleh CV.Usaha Bersama Sebagai Suplier PT.Fumakilla Berbasis Web. Sedangkan beberapa manfaat yang diharapkan dari Aplikasi ini adalah sebagai berikut :

1. Mempermudah Objek Penelitian dalam Pemesanan dan pengiriman Barang dari suplier ke pemesan.

2. Dapat Memberikan informasi data stok dan laporan penjualan untuk CV.Usaha Bersama

\section{LITERATUR}

Menurut Marwan (Marwan, 1991) Penjualan adalah suatu usaha yang terpadu untuk mengembangkan rencanarencana strategis yang diarahkan pada usaha pemuasan kebutuhan dan keinginan pembeli, guna mendapatkan penjualan yang menghasilkan laba, sedangkan Menurut Shim (Shim, 2001) : "Penjualan adalah Penerimaan yang diperoleh dari pengiriman barang dagangan atau dari penyerahan pelayanan dalam bursa sebagai barang pertimbangan. Pertimbangan ini dapat dalam benuk tunai peralatan kas atau harta lainnya. Pendapatan dapat diperoleh pada saat penjualan, karena terjadi pertukaran, harga jual dapat ditetapkan dan bebannya diketahui”. Untuk penjualan dimasa sekarang tidak hanya dilakukan secara langsung (direct selling) tetapi juga bisa dilakukan melalui jarang jauh, baik pemesanan via telepon, atau pun online . prosedur pelayanan penjualan secara online maupun langsung, biasanya melalui beberapa tahapan yaitu pemesanan , persiapan barang dan pengiriman melalui kurir ataupun diambil secara langsung. Selama ini banyak prosedur penjualan terutama di daerah pedesaan masih dilakukan secara manual yaitu melalui catatan dan diketik semi manual menggunakan aplikasi Office, baik Microsoft Office maupun WPS Office (kingsoft). hal ini tentunya memerlukan waktu pengerjaan yang lebih lama dibanding kan cara otomatis yang kami rancang yaitu menggunakan aplikasi pemesanan melalui Website (secara online) . kita akan membahas mengenai aplikasi website . Menurut (Ardhana, 2012) "Web adalah suatu layanan sajian informasi yang menggunakan konsep hyperlink (tautan), yang memudakan sufter (sebutanpara pemakai komputer yang melakukan browsing atau penelusuran informasi melalui internet)".Berdasarkan penjabaran di atas dapat disimpulkan bahwa Web adalah suatu sistem yang dapat menampilkan sebuah informasi di internet, yang berupa teks, gambar, suara maupun video interaktif yang mempunyai kelebihan dapat menghubungkan (link) satu dokumen ke dokumen lainnya (Hypert Text) dan dapat diakses melalui sebuah browser.

Menurut (Sibero, 2013), "PHP adalah pemrograman Interpreter yaitu proses penerjemahan baris kode sumber menjadi kode mesin yang dimengerti Komputer secara langsung pada saat baris kode dijalankan.

Dari penjabaran diatas PHP disebut sebagai bahasa pemograman dimana untuk memungkinkan perancang web yang dinamis dan dapat bekerja sama secara otomatis dalam pengembangan sebuah pembuatan web.

Kehandalan suatu sistem basis data dapat diketahui dari cara kerja pengoptimasinya dalam melakukan proses perintahperintah SQL yang dibuat oleh pengguna maupun program-program aplikasi yang memanfaatkannya. MySQL yang disebut sebagai peladen basis data, mendukung operasi basis data transaksional maupun operasi basis data non-transaksional. Struktur navigasi dari sebuah situs (Malabay, 2019) dikelompokan menjadi 4 struktur yang berbeda, yaitu: Linear, Hirarki, Non Linear, serta Hybrid.

Dimana semua struktur memiliki perbedaan, yaitu: Struktur navigasi linear, merupakan 
struktur yang hanya menggunakan satu alur dan tidak bercabang untuk menelusuri program secara terurut. Struktur navigasi linier hanya mempunyai satu rangkaian cerita yang berurut, yang menampilkan satu demi satu tampilan layar secara berurut menurut urutannya. Tampilan yang dapat ditampilkan pada struktur jenis ini adalah satu halaman sebelumnya atau satu halaman sesudahnya, tidak dapat dua halaman sebelumnya atau dua halaman sesudahnya. Struktur navigasi hirarki biasa disebut struktur bercabang, merupakan suatu struktur yang mengandalkan percabangan untuk menampilkan data berdasarkan kriteria tertentu. Struktur non linear merupakan perkembangan dari struktur navigasi linear, hanya saja pada struktur navigasi non linear diperkenalkan untuk percabangan dan kedudukkan semua page sama, untuk menelusuri program tanpa dibatasi suatu rute. Struktur Navigasi Hybrid adalah Struktur gabungan dimana struktur ini menggabungkan semua struktur yang ada struktur ini dapat memberikan interakksi yang tinggi .

\section{METODE PENELITIAN}

Penelitian ini menggunakan model penelitian Prototyping.

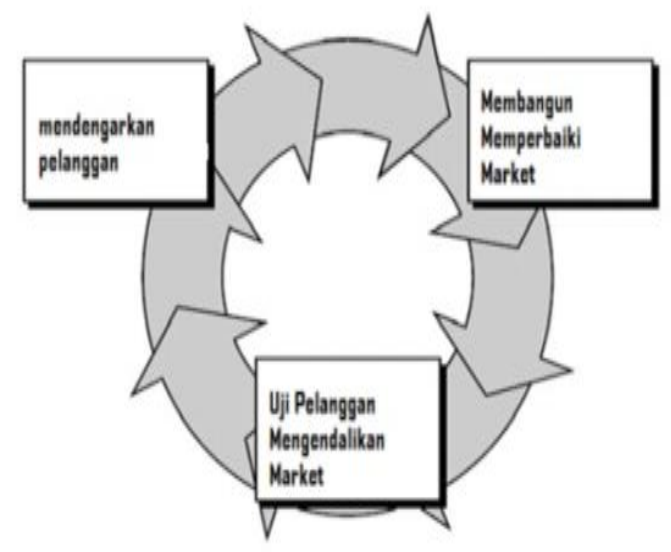

Gambar 1 Model Prototype

Metode prototype atau Prototyping adalah metode pengembangan sistem sistem yang didasarkan pada konsep working model (model kerja). Tujuannya adalah mengembangkan model atau desain menjadi sistem jadi. Dengan menggunakan medode prototyping proses pengembangan sistem akan menjadi lebih cepat dan menghabiskan biaya yang relatif lebih rendah. Artinya cost yang dikeluarkan dalam pengembanngan sistem lebih hemat. Sudah banyak penelitian yang menggunakan metode ini. Pada metode ini terdapat kekurangan dan kelebihan yang tidak terdapat di metode lain.

Proses yang terjadi pada model prototyping yaitu dijelaskan sebagai berikut:

a. User Requirements

Pada tahapan ini pengembang dan klien bertemu dan menentukan tujuan umumnya, kebutuhan yang diketahui serta gambaran bagian-bagian yang akan dibutuhkan berikutnya. Detil kebutuhan mungkin tidak dibicarakan pada tahap ini.

b. Develope Prototype

Pada tahap ini dilakukan perancangan model prototype sistem oleh developer, perancangan sistem dilakukan secara cepat dan rancangan diusahakan mewakili semua aspek software yang telah diketahui. Alur sistem yang berjalan ini di CV. Usaha Bersama dapat dilihat pada flowchart dibawah ini:

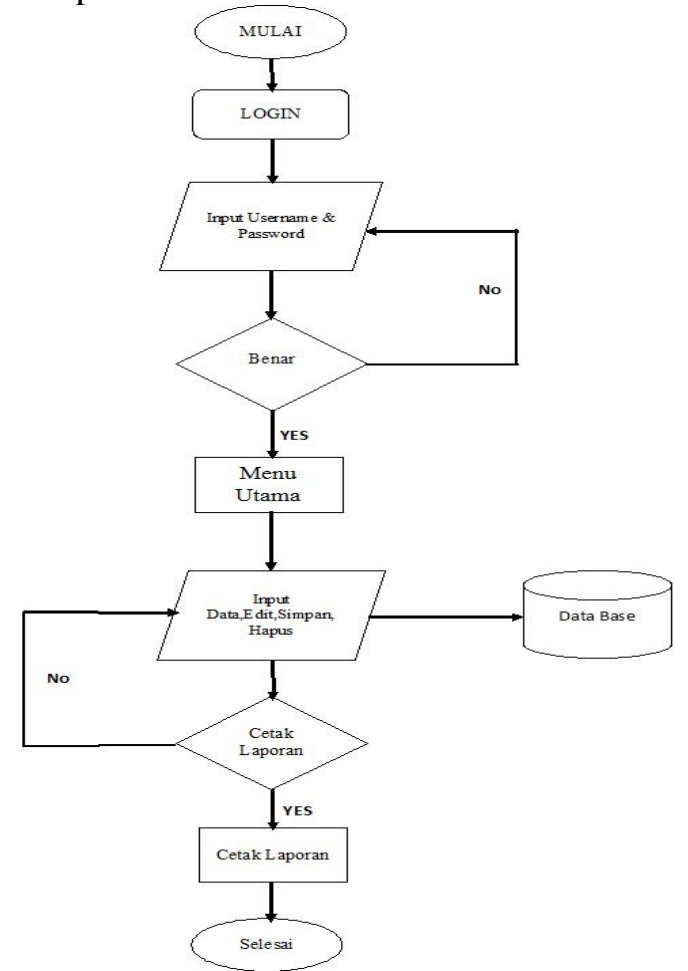

Gambar 2 Flowchart untuk Sistem Yang Diusulkan 


\section{c. Revise Prototype}

Pada tahap ini dilakukan evaluasi prototype sistem oleh klien. Apabila klien merasa prototype sistem yang telah dikembangkan sesuai dengan keinginannya maka prototype tersebut dapat digunakan, akan tetapi jika prototype tersebut tidak sesuai, maka prototype tersebut akan dilakukan revisi dan digunakan sebagai acuan dalam memperjelas kebutuhan software dan kemudian dikembangkan prototype selanjutnya. Siklus ini (develop-revise prototype) akan terus berlangsung hingga didapatkan prototype sistem yang sesuai dengan kebutuhan klien atau user. Keunggulan dan kelemahan pada pengembangan software menggunakan metode prototyping. Keunggulan:

1. Meningkatnya komunikasi antara user dan developer

2. Peningkatan peran aktif user didalam proses pengembangan

3. Peningkatan efisiensi waktu

4. Implementasi sistem menjadi lebih mudah karena user turut berperan aktif didalam proses pengembangan

Kelemahan:

1. Kurangnya fitur keamanan dan kontrol pada prototype akhir system

2. Sistem akan sulit terbentuk jika proses evaluasi pada siklus prototype tidak mendapatkan titiktemu.

3. Dapat menyebabkan dokumentasi akhir yang tidak lengkap

4. Developer lebih sulit mengendalikan ekspektasi user.

Kami membuat diagram UML untuk kebutuhan sistem yang kami buat. Salah satu jenis UML diagram yang kami buat adalah Activity Diagram . Activity Diagram juga dapat menggambarkan proses parallel yang memungkinkan terjadi pada beberapa eksekusi. Sebuah aktivitas dapat direalisasikan oleh satu case atau lebih. Aktivitas menggambarkan proses yang berjalan, sementara case menggambarkan bagaimana actor menggunakan system tersebut untuk melakukan aktivitas.

Berikut adalah gambaran umum activity diagram yang dibuat untuk penelitian ini :

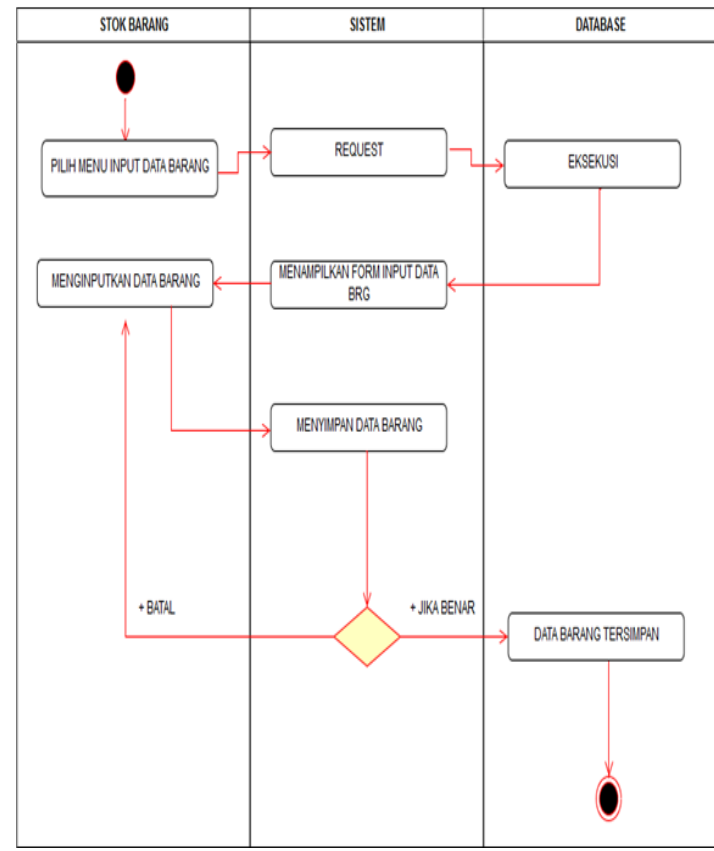

Gambar 3 Activity Diagram Untuk Penelitian

\section{ANALISIS PERANCANGAN DAN IMPLEMENTASI}

Dalam pembuatan rancangan aplikasi maka diperlukan Proses-proses untuk memenuhi kebutuhan fungsional sistem yang akan dibangun :

1. Sistem harus mampu melakukan proses login, apabila pengguna memasukkan username dan password dengan benar maka sistem akan menampilkan halaman utama.

2. Sistem harus mampu melakukan pengolahan data ketika pengguna melakukan inputan pada menu - menu yang terdapat pada menu utama.

3. Sistem harus mampu melakukan pengeditan data ketika pengguna melakukan perubahan data.

4. Sistem harus mampu melakukan penghapusan data ketika pengguna melakukan penghapusan data.

5. Sistem harus mampu menghasilkan laporan.

Selain Kebutuhan Fungsional , pembuatan aplikasi memerlukan rancangan dan desain tampilan aplikasi sebelum dibuat. Rancangan dibuat menggunakan Balsamiq Mockup dan 
pencil . Salah satu rancangan yang paling utama yaitu design Form Login.

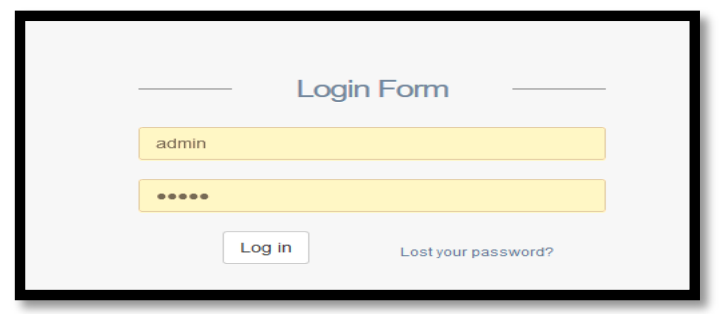

Gambar 4 Design Login Form

Tampilan Menu Utama atau dashboard ialah tampilan pertama setelah admin berhasil login yang mana terdiri dari beberapa submenu aplikasi.

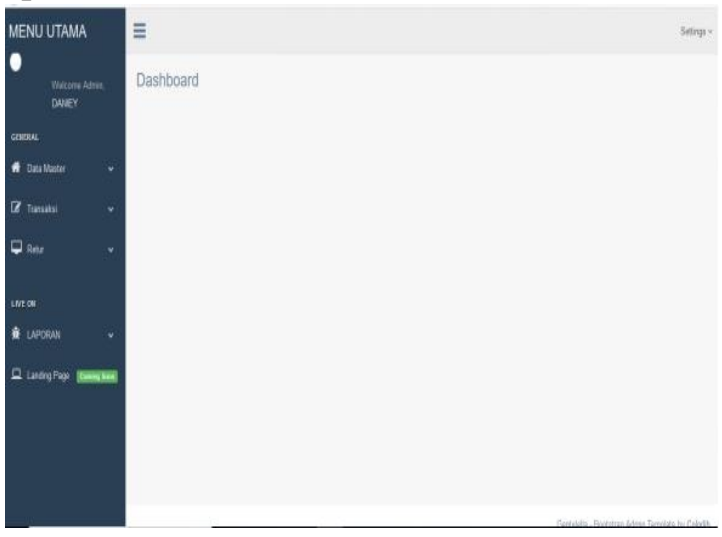

Gambar 5 Form Tampilan Menu Utama / dashboard

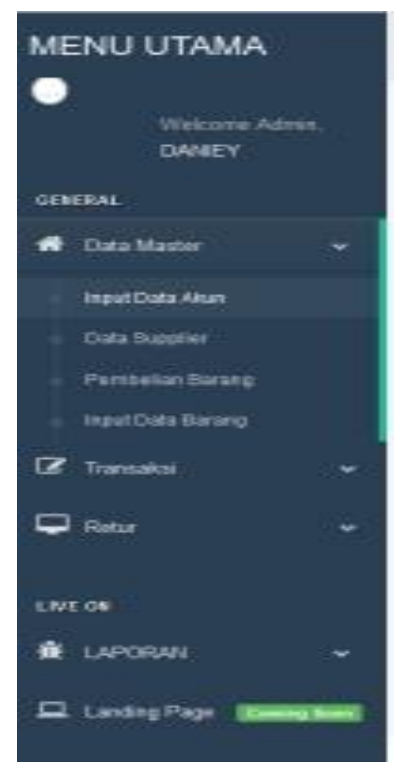

Gambar 6 Menu Utama
ఏ

Pervialan Barang

Ado penvalan

Nonda

Now barm

1)

1)

Nenspertite

hand:

16e:

Ansolwary.

Hugn

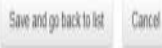

Gambar 7 Form Penjualan Barang

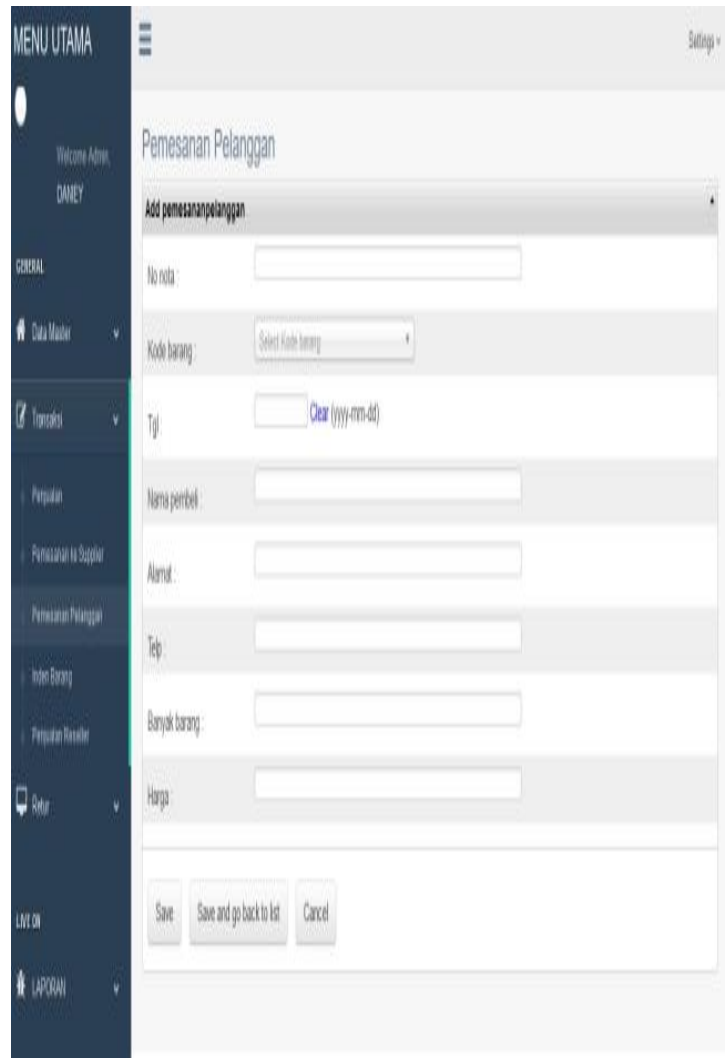

Gambar 8 Form Pemesanan Pelanggan 


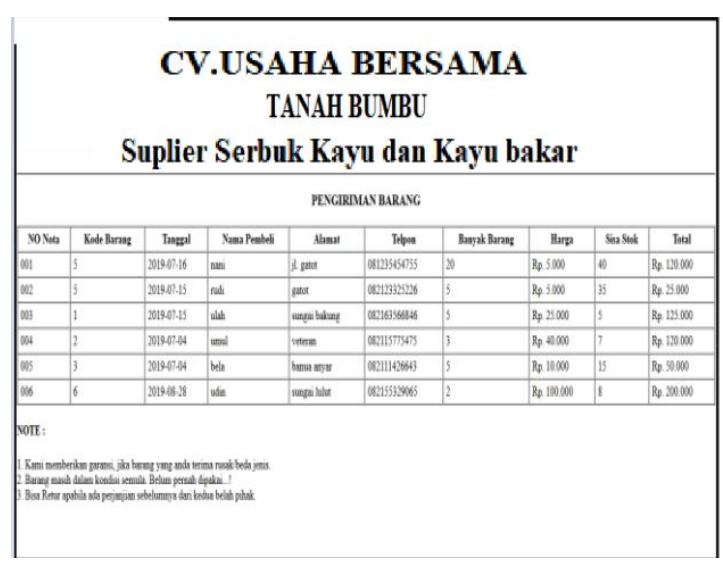

Gambar 9 Laporan Pemesanan Barang

Selanjutnya adalah Tahap pengujian diperlukan terhadap sistem yang telah diimplementasikan untuk mengetahui apakah sistem tersebut berjalan dengan baik dan bebas dari kesalahan. Pada tahap ini, menggunakan metode pengujian unit dengan pendekatan black-box testing yang bertujuan untuk menunjukan fungsi perangkat lunak baik dalam hal pengoperasian maupun kesesuaian antara input dan output.

Black Box Testing adalah suatu pengujian yang dilakukan hanya untuk mengamati hasil dari eksekusi pada software tersebut. Pengamatan hasil ini melalui data uji dan memeriksa fungsional dari perangkat lunak itu sendiri. Jadi dapat dianalogikan seperti kita melihat suatu kotak hitam. Dimana kita hanya bisa melihat penampilan pada luarnya saja, tanpa mengetahui apa yang ada dibalik kotak hitam tersebut. Pengujian black box testing ini juga mengevaluasi hanya pada tampilan luarnya saja (interface), fungsionalnya dan tidak melihat atau mengetahui apa yang sesungguhnya terjadi di dalam proses detilnya. Namun hanya mengetahui proses input dan output-nya saja.

Tabel 1 Pengujian Blackbox data pemesanan pelanggan

\begin{tabular}{|l|l|ll|l|}
\hline 1 & Data & - & Tambah Data & \\
Pemesanan & & Pemesanan & \\
Pelanggan & & Pelanggan & \\
& & - & Simpan Data & Blackbox \\
& & Pemesanan & \\
& & & Pelanggan & \\
& & Edit Data & \\
& & Pemesanan & \\
& & & \\
& & & \\
& & & \\
\end{tabular}

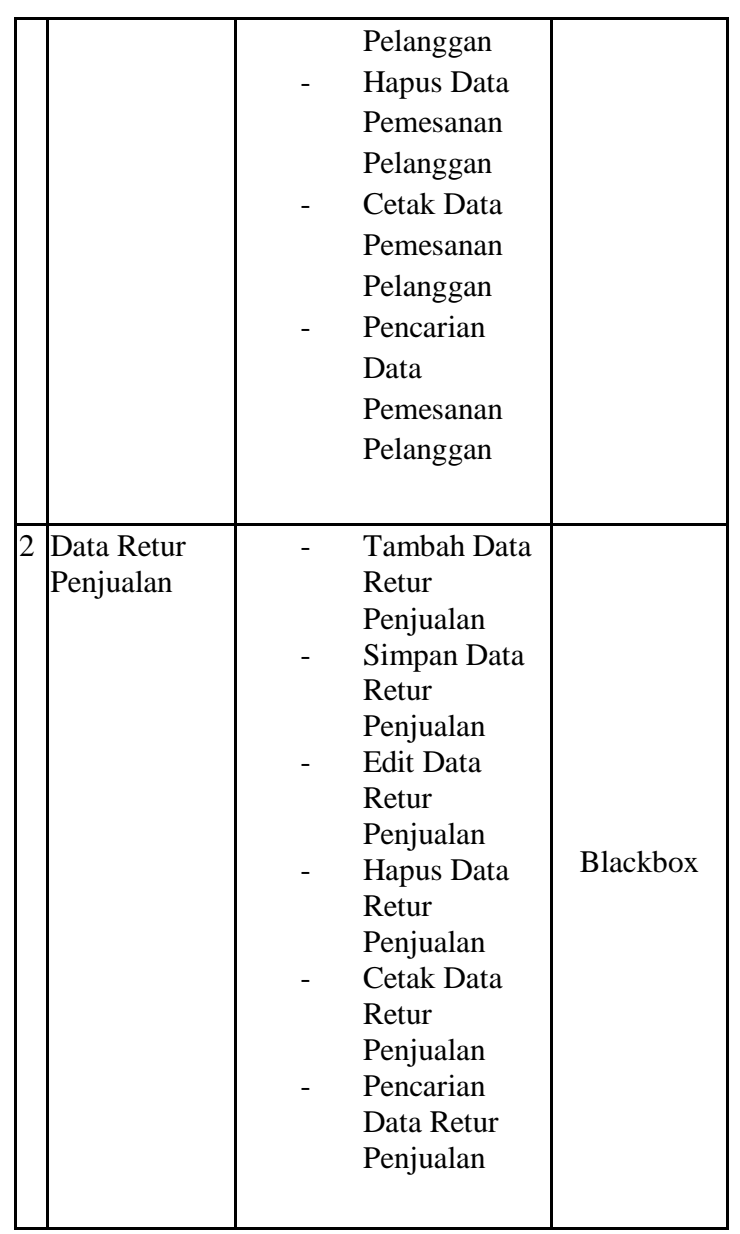

Selanjutnya Hasil dari pengujian dari beberapa menu atau form yang sudah diuji

Tabel 2 Hasil Pengujian

\begin{tabular}{|l|l|l|l|l|}
\hline No & \multicolumn{1}{|c|}{$\begin{array}{c}\text { Data } \\
\text { Masukkan }\end{array}$} & $\begin{array}{c}\text { Hasil yang } \\
\text { diharapkan }\end{array}$ & Hasil & Kesimpulan \\
\hline 1 & $\begin{array}{l}\text { Klik menu } \\
\text { 'input Data } \\
\text { Barang' }\end{array}$ & $\begin{array}{l}\text { Masuk halaman } \\
\text { input Data } \\
\text { Barang dan } \\
\text { tampil form } \\
\text { input Data } \\
\text { Barang }\end{array}$ & Sesuai & Berhasil \\
\hline 2 & $\begin{array}{l}\text { Mengisi form } \\
\text { input Data } \\
\text { Barang lalu } \\
\text { klik tombol } \\
\text { simpan' }\end{array}$ & $\begin{array}{l}\text { Data akan } \\
\text { tersimpan } \\
\text { kedalam } \\
\text { database dan } \\
\text { masuk ke } \\
\text { halaman Data } \\
\text { Barang }\end{array}$ & Sesuai & Berhasil \\
\hline 3 & $\begin{array}{l}\text { Klik menu } \\
\text { View data } \\
\text { Data Barang }\end{array}$ & $\begin{array}{l}\text { Menampilkan } \\
\text { halaman data } \\
\text { Barang }\end{array}$ & Sesuai & Berhasil \\
\hline
\end{tabular}




\begin{tabular}{|l|l|l|l|l|}
4 & $\begin{array}{l}\text { Klik icon } \\
\text { 'edit' pada } \\
\text { data Barang } \\
\text { lalu klik } \\
\text { tombol 'edit' } \\
\text { pada form } \\
\text { edit data } \\
\text { Barang }\end{array}$ & $\begin{array}{l}\text { Menampilkan } \\
\text { form edit data } \\
\text { Barang dan data } \\
\text { Barang diedit. }\end{array}$ & Sesuai & Berhasil \\
\hline 5 & $\begin{array}{l}\text { Klik icon } \\
\text { hapus' pada } \\
\text { data Barang }\end{array}$ & $\begin{array}{l}\text { Data Barang } \\
\text { terhapus dari } \\
\text { database dan } \\
\text { tabel }\end{array}$ & Sesuai & Berhasil \\
\hline 6 & $\begin{array}{l}\text { Klik tombol } \\
\text { 'laporan } \\
\text { Barang' pada } \\
\text { submenu } \\
\text { laporan }\end{array}$ & $\begin{array}{l}\text { Mencetak } \\
\text { laporan data } \\
\text { Barang } \\
\text { keseluruhan }\end{array}$ & Sesuai & Berhasil \\
\hline
\end{tabular}

\section{KESIMPULAN}

Dengan adanya Prototype Aplikasi Pemesanan Dan Pengiriman Serbuk Kayu Oleh CV.Usaha Bersama Sebagai Suplier PT.Fumakilla Berbasis Web, tentunya Memberikan keuntungan kompetitif bagi perusahaan secara keseluruhan dengan penghematan waktu, tenaga dan biaya.

\section{REFERENSI}

[1]Alfah, R., 2016. Implementasi Peningkatan Citra X-Ray Menggunakan Komparasi Clip Limit Clahe Dengan Global Threshold Metode Graythresh. Technologia, 7(Vol 7, No 4 (2016)), pp. 21-27.

[2] Ardhana. (2012). Menyelesaikan Website 30 Juta ! Jakarta: Jasakom.

[3] Faridi, M. (2015). Fitur Dahsyat Sublime Text 3. Surabaya: LUG. [4] Hutahaean, J., 2014. Konsep Sistem Informasi. Yogyakarta: CV. Budi Utama.

[4] Malabay, E. d. (2019, 07 rabu). Retrieved from docplayer:

https://docplayer.info/78430080-Bab-iilandasan-teori.html

[5] Marwan. (1991). Marketing. Yogyakarta: UPP-AMP YKPN.

[6] Pohan. (2012). Pemograman Web Dengan HTML. Bandung: Informatika
[7] Rina Alfah, T. V. R., 2018. Sistem EPrescribing Dan BARCODE SYSTEM Untuk Resep Obat Di Rumah Sakit. Jurnal Teknologi Informasi Universitas Lambung Mangkurat (JTIULM), 03(Vol. 3 No. 2 (2018)), pp. 59-70.

[8] Shim, J. G. (2001). pedoman lengkap langkah-langkah penganggaran. Surakarta: Erlanggan.

[9] Sibero. (2013). Web Programming Power Pack. Yogyakarta: Mediakom 